TEME, г. ХІІ, бр. 1, јануар - март 2018, стр. 1-15

\begin{tabular}{lr}
\hline \hline Оригиналан научни рад & DOI: $10.22190 /$ TEME1801001D \\
Примљено: 11.5 .2017$. & UDK 376:316.64-051
\end{tabular}

Ревидирана верзија: 7. 11. 2017.

Одобрено за штампу: 12. 3. 2018.

\title{
ATTITUDES TOWARDS INCLUSIVE EDUCATION FROM THE PERSPECTIVE OF TEACHERS AND PROFESSIONAL ASSOCIATES
}

\author{
Srboljub Đorđević ${ }^{1 *}$, DraganaStanojević ${ }^{1}$, Lucija Đorđević ${ }^{2}$ \\ ${ }^{1}$ University of Niš Faculty of Pedagogy in Vranje, Vranje, Serbia \\ ${ }^{2}$ SSS "Vule Antić" Vranje, Serbia \\ *dr.djordjevic@yahoo.co.uk
}

\begin{abstract}
The paper analyzes opinions and attitudes of teachers and professional associates towards inclusive education and towards students with special needs in the Republic of. Serbia and Norway, and they are compared with each other. The research was conducted in fifteen regular elementary schools located on the territory of the Republic of Serbia on a sample of 220 teachers and 22 professional associates, as well as with 10 teachers and 6 professional associates from two primary schools in Oslo, Norway. The research used descriptive, analy tical and comparative methods, and survey as the research technique. Based on the obtained research results, it is concluded that there is a generally positive attitude of teachers and professional associates in the Republic of Serbia towards inclusive education of children with special needs. Such results provide a guarantee for further perspective and implementation of inclusive education in the Republic of. Serbia. The conducted research did not show statistically significant differences in the attitudes of male and female respondents regarding the inclusive education of children with special needs. However, the attitudes of teachers and professional associates in the Republic of Serbia towards the inclusive education of children with special needs differ statistically and teachers generally have more positive attitude towards all categories of students. The obtained results also make it imperative to conclude that there is still the need to work on improving attitudes towards students with special needs in order to create certain support for further implementation of inclusive education.
\end{abstract}

Key words: inclusive education, teacher, supporting staff, students with special needs.

\section{СТАВОВИ ПРЕМА ИНКЛУЗИВНОМ ОБРАЗОВАњУ ИЗ ПЕРСПЕКТИВЕ УЧИТЕЉА И СТРУЧНИХ САРАДНИКА}

\section{Апстракт}

У раду се анализирају мишљења и ставови учитеља и стручних сарадника према инклузивном образовању и ученицима са посебним потребама у Републици Србији и Норвешкој и исти међу собно упоређују. Истраживање је спроведено у 
петнаест редовних основних школа које се налазе на територији Републике Србије, на узорку од 220 учитеља и 22 стручна сарадника, као и 10 учитеља и 6 стручних сарадника двеју основних школа града Осла у Норвешкој. У истраживању је коришћена дескриптивна, аналитичка и компаративна метода, а од техника истраживања анкетирање. На основу добијених резултата истраживања, закључује се да постоји, уопштено гледано, позитиван став учитеља и стручних сарадника у Републици Србији према инклузивном образовању деце са посебним потребама. Овакви резултати пружају гаранцију за даљу перспективу и примену инклузивног образовања у Републици Србији. Извршеним истраживањем нису уочене статистички значајне разлике у ставовима мушких и женских испитаника по питању инклузивног образовања деце са посебним потребама. Међутим, ставови учитеља и стручних сарадника у Републици Србији према инклузивном образовању деце са посебним потребама статистички се разликују и учитељи уопштено имају позитивнији став према свим категоријама ученика. Добијени резултати, такође, императивно намећу закључак да се и даље мора радити на побољшању ставова према ученицима са посебним потребама како би се стварала одређена потпора за даље спровођење инклузивног образовања.

Кључне речи: инклузивно образовање, учитељ, стручни сарадник, ставови, ученици са посебним потребама.

\section{INTRODUCTION}

Inclusive education as a civil movement is relatively new in the world and in the European region. It has been created and developed as a movement since the middle of the twentieth century. Its appearance in the Western European countries was linked to the context of human rights and established in the Universal Declaration of Human Rights in 1948, and later in 1989 in the Convention on the Rights of the Child. Since then onwards, this framew ork has been developing through a series of documents of the United Nations and other international documents, in which certain strategic guidance and standard rules of equalizing the position of different marginalized and vulnerable social groups at the margins of social interest were determined, as well as the need for specific and wider social action that would meet those needs and inclusion of these groups in regular social activities, notably the creation of the most desirable forms of education for all, particularly in actualizing the right to regular education.

"Quality education for all and inclusion as a system preference are linked to the characteristics of openness and fairness of the education system. The development of inclusive characteristics of education involves first of all the development of inclusive policies, then the improvement of inclusive practice, as well as the appropriate development of inclusive values, both at the system level and at the level of individual institutions. The development of an inclusive dimension of education primarily implies certain support to the diversities through building cooperation and acceptance, active involvement of every child in education, improvement of teaching itself and learning environment, too, as well as removing obstacles in the learning process of each child" (Đorđević, 2010, p. 171) 
Inclusion as a term in Serbia appeared in 2000-2001 to become in recent years perhaps one of the most commonly used terms when talking about changes in education. Its use has become more common with the introduction of the concept of quality education for all, and often the term inclusion is identified with it, which can be understood if one takes into account the fact that inclusive education presupposes the ability of school to provide good education to all children, regardless of certain differences among them. The very notion of inclusion is associated with the processes of democratization in society and in education, and in this context it is often talked about social inclusion in a broader sense, as well as about educational inclusion, when that means involvement of students from the so-called marginalized groups in education. (Đorđević et al., 2016)

In the Republic of Serbia, inclusive education was legally justified by the Law on the Foundations of Education passed in September 2009. This law abolished enrollment policy which discriminates and does not provide equal education for all, and it was determined that since the school year 2010/2011 all children have been included in regular education system.

Directing inclusive policy as well as conducting inclusive practice is irrelevant without stimulating community in which differences are respected, inclusive values are esteemed and relations of cooperation are developed. Changing of attitudes towards inclusion and persons with special needs is necessary to even talk about an inclusive culture.

This approach to inclusive education, among other things, necessarily focuses on the issue of attitudes of teachers and professional associates to inclusive education of children with special needs as an important factor (certainly not the only one) on which in many ways the realization of inclusion depends on. Positive attitude and positive thinking and behavior related to them can be significant support for inclusive education. Of course that opinions, attitudes and values differ from each other according to their resistance to the requirements for change, stability over time, as well as whether they are based on direct or indirect experience with the object attitude (Martin and Vieceli, 1988; Najman Hižman et al., 2008; Sharma et al., 2006; Leutar and Štambuk, 2006; Tak-fai Lau and Cheung, 1999; Ross-Hill, 2009).

Not a small number of domestic and international studies points to certain differences in attitudes with respect to different categories of impairments or disabilities, in which particularly is emphasized stigmatization of individuals with mental disabilities compared to individuals with physical disabilities or sensory disabilities in older school children, adolescents and adults (Avramidis et al., 2000; Hodkinson, 2007; Hrnjic a and Sretenov, 2003; Lifshitz et al., 2004; Najman Hižman et al., 2008; Tur-Kaspa et al., 2000), while the results obtained in pre-school age children are reversed (Laws and Kelly, 2005).

There are also studies that conclude that the process of successful implementation of inclusive education requires well-prepared school 
environment, adequate programs, better equipped schools, and adequate professional training of teachers (Angelides et al., 2006; Buell et al., 1999).

In line with the trends that have recently been devoted to the process of inclusion of children with special needs, a series of studies were conducted which in focus of the research had the examination of the attitudes of educators and teachers towards the inclusion of children with disabilities in regular schools. In these studies, the importance of the attitudes to the success of inclusion in pre-school, primary and secondary education is highlighted (Scruggs and Mastropieri, 1996; Avramidis and Norwich, 2002; Kunstmann, 2003; Rose, 2001; Pearce, 2009; Carter and Hughes, 2006).

The attitudes may be defined as systems of assessment, emotion or tendency to a particular person or appearance (Avramidis et al., 2000).

The structure of attitudes basically consists of three components:

1. Cognitive Component- represents a certain grade of qualities and values of a person or appearance. Evaluation can be positive or negative, whereby the person or appearance is evaluated as good or bad, beneficial or harmful, desirable or undesirable.

2. Affective or Emotional Component - makes sensitive aspect to the attitude wherein the value judgment is defined as I like / I do not like, or as a pleasant (positive ratio) and uncomfortable (negative ratio).

3. Behavioral or Action Component- reflects certain behavior towards a person or appearance which is in accordance with the internal attitudes. Thus, for example, if a positive attitude is present, behavior will include the approval, support, whereas a negative attitude implies rejection, avoiding, even direct prevention and attack (Avramidis et al., 2000).

Bearing in mind the above stated, we were particularly interested to examine the opinions and attitudes of teachers and professional as sociates in the Republic of Serbia towards inclusive education of children with special needs and compare the same with the views of teachers and staff in Norway.

\section{RESEARCH METHOD}

Starting from what we pointed out can be clearly concluded that on the way of implementation of inclusive education, among others, teachers and professional associates are an important factor. On this basis, the object of our study was to investigate opinions and attitudes of teachers and professional associates towards inclusive education and children with special needs. We were primarily interested in the affective or emotional component of attitudes.

It is known that attitudes cannot be measured directly, but they can be expressed through certain indicators. For this research, we constructed two questionnaires - one for teachers and one for associates, which were made in accordance with the aim of research. The questionnaires consisted of closed questions with a few open-ended questions. The research used descriptive, analytical and comparative methods, and survey as the research technique. 
The questionnaire for teachers contained fifteen specific questions and the sixteenth question was substantially a free question related to the appropriate problem the survey asked for, but had not covered by the above questions, so adequate space for teachers' REMARKS was left. Questions referred to many thematic areas: about aw areness of teachers of students with special needs, about their opinion on the inclusion of students with special needs in regular classes of primary school, about the problems of inclusion as a process, and other.

The questionnaire for associates included twenty-three questions also related to the investigated problem within the same thematic areas as well as for teachers and twenty-fourth was substantially free question.

The nature and significance of research of the chosen problem was the decisive factor for the selection of the survey sample. The survey was organized in fifteen regular primary schools, which are located on the territory of the Republic of Serbia, on a sample of 220 teachers from first to fourth grade and 22 professional associates, as well as on 10 teachers and 6 professional associates of two primary schools in Oslo in Norway. The distribution pattern of teachers and professional associates in the schools is given in Table 1. We would mention that because of the differences in the sample size, the so-called Yates correction was used in processing the results of the research.

Table 1. Pattern of teachers and professional associates

\begin{tabular}{|c|c|c|c|}
\hline \multirow{2}{*}{$\begin{array}{l}\text { Republic of Serbia } \\
\text { Primary school }\end{array}$} & \multicolumn{2}{|r|}{ Number } & \multirow[t]{2}{*}{ Total } \\
\hline & Teachers & Professional as sociates & \\
\hline „B. Stanković“"-Vučje & 28 & 1 & 29 \\
\hline „D. Obradović“ - Niš & 15 & 1 & 16 \\
\hline „V.S.Karadžić“-Poža revac & 21 & 1 & 22 \\
\hline „D. Obradović“- Požarevac & 15 & 2 & 17 \\
\hline „Miloš Savić““- Poljana & 4 & - & 4 \\
\hline „I.L.Ribar“-V.Gradište & 32 & 2 & 34 \\
\hline „M.Živanović“-Srednjevo & 14 & 1 & 15 \\
\hline „V.S.Karadžić“-Mojilovac & 10 & 1 & 11 \\
\hline „D.Marković“- Kruševac & 16 & 1 & 17 \\
\hline „D. Obradović“- Kruševac & 19 & 3 & 22 \\
\hline „V prol. brigade“-Žabare & 8 & 1 & 9 \\
\hline „VoždKarađorđe” Leskovac & 6 & 2 & 8 \\
\hline „K. Stamenković“ Leskovac & 5 & 2 & 7 \\
\hline „D. Obradović“ - Vranje & 14 & 2 & 16 \\
\hline „R.Domanović“ - Vranje & 13 & 2 & 15 \\
\hline Total & 220 & 22 & 242 \\
\hline Norway & \multicolumn{2}{|r|}{ Number } & Total \\
\hline Primary school & Teachers & Professional as sociates & \\
\hline „Tveita skole“- Oslo & 5 & 3 & 8 \\
\hline „Lutvann skole“- Oslo & 5 & 3 & 8 \\
\hline Total & 10 & 6 & 16 \\
\hline
\end{tabular}




\section{RESEARCH RESULTS}

Due to the chosen research subject, goals and tasks that we set up, the most signific ant results obtained from the questionnaire will be presented together in table and graphically for all schools, not individually for each school.

Table 2. Evaluation of teachers and professional associates about their awareness of students with special needs (Answers to the question from Questionnaire: Do you think that you are sufficiently informed about students with special needs?)

\begin{tabular}{lrrrrrrrrrr}
\hline & \multicolumn{2}{c}{ Yes } & \multicolumn{2}{c}{ No } & \multicolumn{2}{c}{ Partially } & \multicolumn{2}{c}{$\begin{array}{c}\text { Not } \\
\text { interested }\end{array}$} \\
\cline { 2 - 12 } R. Serbia & f & \multicolumn{1}{c}{$\%$} & \multicolumn{1}{c}{ f } & \multicolumn{1}{c}{ Total } \\
\hline Teachers & 32 & 14,55 & 43 & 19,55 & 145 & 65,90 & - & - & 220 & 100 \\
Associates & 16 & 72,7 & - & - & 6 & 27,3 & - & - & 22 & 100 \\
\hline Norway & & & & & & & & & & \\
Teachers & 7 & 70 & - & - & 3 & 30 & - & - & 10 & 100 \\
Associates & 6 & 100 & - & - & - & - & - & - & 6 & 100 \\
\hline
\end{tabular}

The frequency of responses to the question 'Who makes the category of students with special needs?' is presented in Table 3.

Table 3. The frequency of teachers' and professional associates' responses to the question: "who makes the category of students with special needs?"

\begin{tabular}{lrrrrr}
\hline Question and answers: & \multicolumn{5}{c}{ Republic of Serbia } \\
\cline { 2 - 6 } & $\begin{array}{c}\text { Teachers' } \\
\text { Answers }\end{array}$ & $\begin{array}{c}\text { Associates' } \\
\text { answers }\end{array}$ \\
\cline { 2 - 6 } are students with special needs? & \multicolumn{1}{c}{ f } & \multicolumn{1}{c}{ f } & $\%$ \\
\hline Children with difficulties in learning and behaviour & 32 & 14,55 & - & - \\
Children with congenital dis abilities & 26 & 11,82 & - & - \\
Unfavorable social conditions & 13 & 5,90 & - & - \\
Children with emotional difficulties & 29 & 13,20 & 9 & 40,91 \\
Children with hearing impairment & 58 & 26,36 & 15 & 68,18 \\
Children with visual impairments & 83 & 37,73 & 22 & 100 \\
Children with mental disabilities & 37 & 16,82 & 22 & 100 \\
Children with physical defects & 72 & 32,73 & 14 & 63,64 \\
Children above the average & 35 & 15,90 & - & - \\
Gifted children & 19 & 8,63 & - & - \\
Total: & 404 & - & 82 & - \\
\hline
\end{tabular}

Among other things, we asked teachers and professional associates to comment on their attitude towards the inclusion of children with special needs in mainstream primary schools. The obtained answers are shown in Figure 1 . 


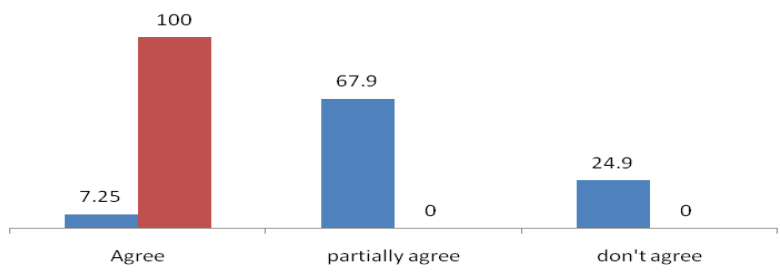

Figure1. The attitudes of teachers and professional associates towards the inclusion of children with special needs in mainstream primary schools

Special Educational Needs and the Possibility of Inclusion

According to the objective of research, the respondents were asked to comment on the acceptance of inclusion according to the categories of children with special needs (where we determined the mean of the full scale of responses from 1-complete inclusion to 5-complete segregation). The obtained answers of teachers and professional associates in the Republic of Serbia are shown in graphs 2 and 3.

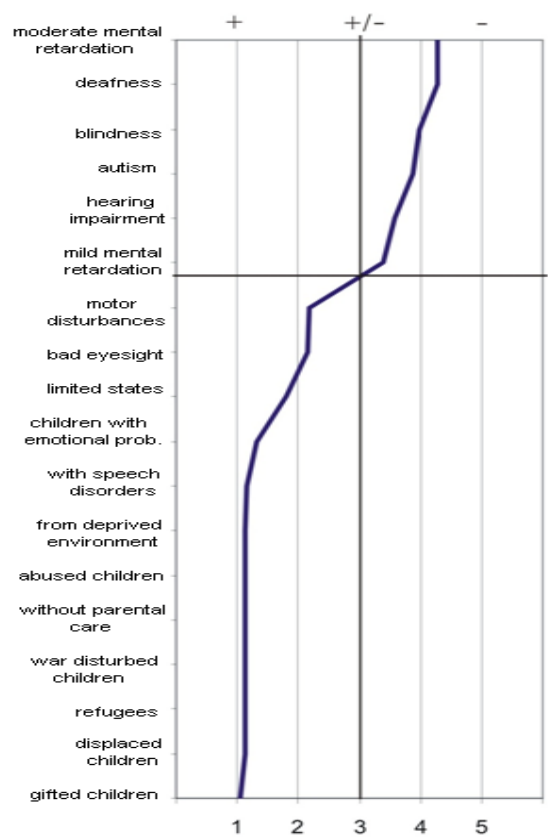

Graph 2. $M$ of teachers' attitudes in

$R$. Serbia connected to the acceptance of inclusion according to categories of children with special needs $(M=2,21)$

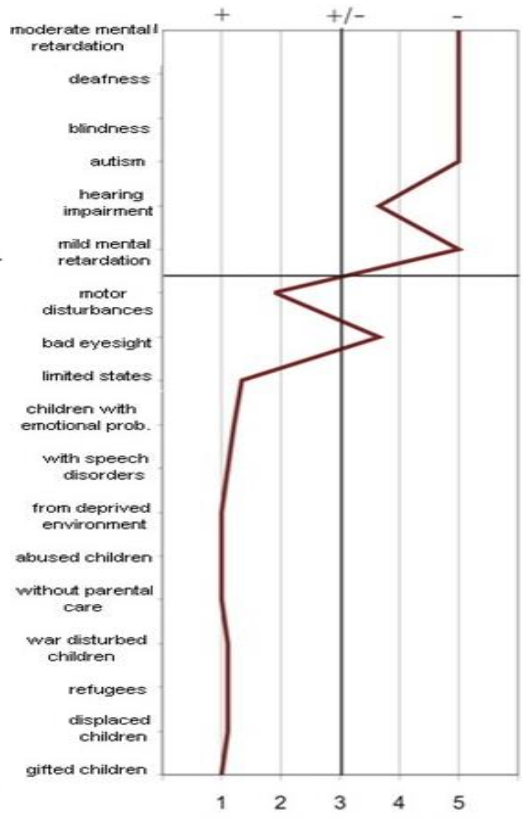

Graph 3. M of associates' attitudes in $R$. Serbia connected to the acceptance of inclusion according to categories of children with special needs $(M=2,51)$

The significance of differences in the attitudes of teachers and professional associates in the Republic of Serbia was tested by the $\chi^{2}$ - test 
with the use of the so-called Yates' correction due to the number of frequencies of certain categories of answers. Table 4 shows the values of the $\chi^{2}$ - test by categories of students and by the level of statistical significance.

The obtained results of research on the attitudes of teachers and associates in Norway towards certain categories of students with special needs are shown in Graphs 4 and 5 and in Table 5.

Table 4. The difference in attitudes of teachers and professional associates by categories of students in the Republic of Serbia

\begin{tabular}{lrr}
\hline Category of students & $\chi^{2}$ & sig \\
\hline gifted children & 1,02 & \\
displaced children & 0,64 & \\
refugees & 0,64 & \\
war disturbed children & 0,52 & \\
children without parental care & 3,11 & \\
abused children & 3,11 & \\
children from deprived environments & 3,28 & \\
children with speech dis orders & 0,69 & \\
children with emotional problems & 4,84 & \\
limited state intelligence & 7,59 & 0,05 \\
bad eyesight & 47,22 & 0,01 \\
motor disturbances & 17,03 & 0,01 \\
mild mental retardation & 48,48 & 0,01 \\
hearing impairment & 108,35 & 0,01 \\
autism & 28,06 & 0,01 \\
blindnes & 7,69 & 0,05 \\
deafness & 21,08 & 0,01 \\
moderate mental retardation & 11,64 & 0,01 \\
\hline
\end{tabular}

Table 5. The difference in attitudes of teachers and professional associates in Norway by categories of students

\begin{tabular}{|c|c|c|}
\hline Category of students & $\chi^{2}$ & sig \\
\hline \multicolumn{3}{|l|}{ gifted children } \\
\hline \multicolumn{3}{|l|}{ dis placed children } \\
\hline \multicolumn{3}{|l|}{ refugees } \\
\hline \multicolumn{3}{|l|}{ war dis turbed children } \\
\hline \multicolumn{3}{|l|}{ children without parental care } \\
\hline \multicolumn{3}{|l|}{ abused children } \\
\hline \multicolumn{3}{|l|}{ children from deprived environments } \\
\hline \multicolumn{3}{|l|}{ children with speech disorders } \\
\hline children with emotional problems & 0,34 & \\
\hline \multicolumn{3}{|l|}{ limited state intelligence } \\
\hline \multicolumn{3}{|l|}{ bad eyesight } \\
\hline motor disturbances & 4,64 & \\
\hline \multicolumn{3}{|l|}{ mild mental retardation } \\
\hline \multicolumn{3}{|l|}{ hearing impairment } \\
\hline autism & 15,49 & 0,01 \\
\hline \multicolumn{3}{|l|}{ blindness } \\
\hline deafness & 20,43 & 0,01 \\
\hline moderate mental retardation & & \\
\hline
\end{tabular}




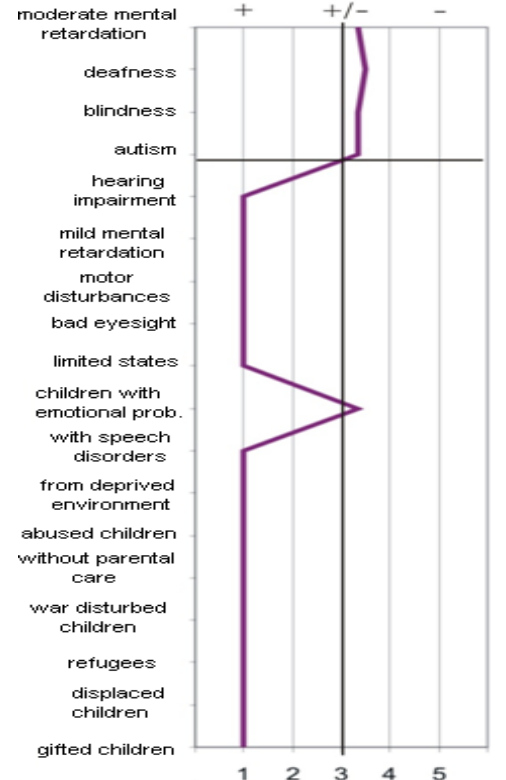

Graph 4. M of teachers' attitudes in Norway connected to the acceptance of inclusion according to categories of children with special needs $(M=1,72)$

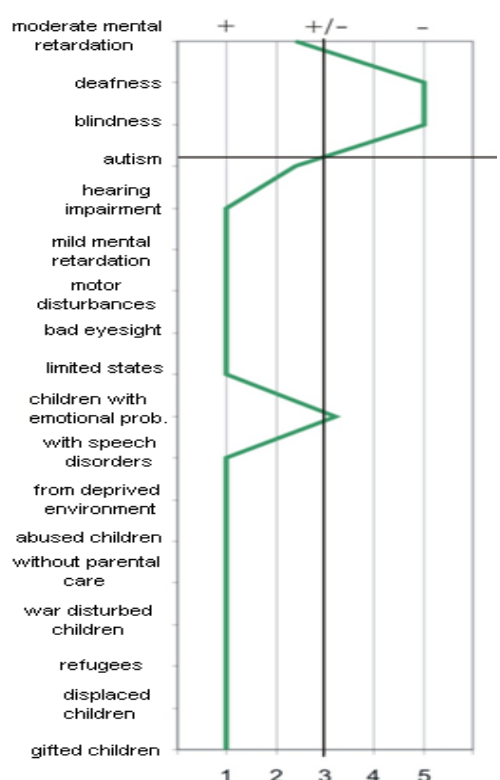

Graph 5. M of associates' attitudes in Norway connected to the acceptance of inclusion according to categories of children with special needs $(M=1,66)$

\section{DISCUSSION}

The results of the subjective evaluation of teachers about their aw areness of students with special needs (presented in Table 2) show that from 220 teachers surveyed in the Republic of. Serbia, only 32 of them or $14.55 \%$ believe they are sufficiently informed about this category of students, while the vast majority of teachers (145 or $65.90 \%)$ consider being partially informed.

The obtained results of subjective evaluations of teachers and professional associates were compared to each other in order to determine if there is a statistic al difference among them. After dividing the difference in the level of awareness of teachers and professional associates in Serbia of students with special needs, we found that among them there is a statistically significant difference (the $\chi^{2}$ - square test $43.27, \mathrm{df}=2, \mathrm{p}>0.01$ ). These results lead to the conclusion about the need of providing additional professional training of teachers, as well as associates, which would strengthen the cognitive component of their attitudes and create preconditions for a further development of positive attitudes and implementation of inclusive education. 
Unlike in Serbia, the distribution of the responses in Norway is mainly in the categories of fully and partially. A certain percentage of teachers (30\%) think that they are partially informed, while all professional associates consider themselves to be fully informed about students with special needs. How ever, the difference in the responses to the level of information of these two categories of the respondents in Norway is not statistically significant (the $\chi^{2}$ - squared test $2.36, \mathrm{df}=1, \mathrm{p}<0.05$ ).

The results of the responses to the question: Who makes the category of students with special needs? (presented in Table 3), confirm the conclusion that teachers in the Republic of Serbia are not sufficiently informed about children with special needs because in their responses only some categories of students with special needs are mostly stated.

The most frequent category of children with special needs is children with visual impairments, which was stated by 83 teachers, or $37.73 \%$, children with physical disabilities, which was stated by 72 or $32.73 \%$ of teachers. From the responses of professional associates on this issue, it can be seen that under special needs they understand only children with disabilities (which is only one category of children with special needs), while the teachers under this term imply a much broader category of students. Based on these responses of professional associates it may be concluded that they do not have enough knowledge about students with special needs, which all 22 professional associates confirmed in their answers to the question: Are you qualified to participate in the work with children with special needs? 17 professional associates or $77.30 \%$ stated that they were not trained, and 5 or $22.70 \%$ that they needed additional training.

Unlike teachers and associates in the Republic of Serbia, the majority of teachers (7 or 70\%) and all associates in Norway stated all categories of students with special needs and everyone felt sufficiently trained to work with children with special needs.

Regarding the attitude of teachers tow ards the inclusion of children with special needs in mainstream primary schools (shown in Figure 1), the majority of the teachers in the Republic of Serbia (131 or $67.90 \%$ ) declared that they partially agree with this proposal, while only 14 or $7.25 \%$ of the teachers fully agree. Contrary to the views of the teachers, all professional associates stated that they do not agree with this proposal.

In contrast to the attitudes of the teachers and professional associates of the Republic of Serbia to the inclusion of students with special needs in mainstream primary schools, their colleagues from Norw ay fully agree with the inclusion of these children in mainstream primary schools.

Our further analysis was focused on determination of the most appropriate institutions for children with disabilities, wherein we set the mean of the full scale with replies (from 1-full inclusion to 5- complete segregation). Based on the results of the performed research on the teachers' attitudes in the Republic of Serbia the arithmetic mean of 2.21 (hypothetical 
zero would be 3 ) is obtained. Thus obtained results of the study (shown in Figure 2) indicate that there is a generally positive attitude of teachers in the Republic of Serbia tow ards inclusive education in primary schools. Only a few categories (mental retardation, autism, deafness and blindness) of students with special needs are on the "negative" side of the scale. Nearly identic al results of the presence of negative attitudes to certain categories of students we encounter in some authors (Avramidis et al., 2000; Hrnjica and Sretenov, 2003; Kasa Hendrickson and Kluth, 2005; Lifshitz et al., 2004).

If we compare the obtained results with the results of research in other countries, we can see that it is interesting that in the Republic of Serbia there is a positive attitude tow ard the students with emotional and behavioral problems, which in other countries is not the case (Scruggs and Mastropieri, 1996; Avramidis and Norwich, 2002; Soodak, Podell and Lehman, 1998). These results, obtained in our study, require deeper analysis, which on this occasion we have not done.

Comparing the results (the arithmetic means) of obtained attitudes of teachers and professional associates in surveyed schools in the Republic of Serbia, in relation to certain categories of students with special needs (show $\mathrm{n}$ in Table 4), significant differences in relation to the category of children with special needs can be observed which, colloquially, in the educational practice of teachers, are described as difficulties in relation to children with special needs who don't have the so-called organic or physiological lack.

Mutual comparison of attitudes towards inclusive education by gender of the respondents does not offer significant differences.

Based on the obtained results of teachers and associates in Norway on certain categories of students with special needs (shown in Graphs 4 and 5), general conclusion can be made that the attitudes of the teachers $(M=1.72)$ and associates $(M=1,66)$ in Norway are more positive compared to the attitudes of the teachers and associates in the Republic of Serbia. The attitudes of teachers and associates in Norway tow ards inclusive education are almost identical to each other in all categories of students with special needs.

Mutual comparison of the teachers' and associates' attitudes tow ards certain categories of students with special needs in Norway we found that a significant difference exists only in the categories of children with autism and hearing problems ( $p>0.01)$. There is a certain difference in the attitudes of teachers and associates in Norway towards children with emotional problems and motor disorders, but this difference is not statistically significant.

Comparing the obtained results of research of the teachers' attitudes tow ards inclusive education in the Republic of Serbia with the views of the teachers from Norway, it is evident that the greatest differences exist between them in the acceptance of children with emotional and behavioral problems, intellectual disabilities, hearing impairment and bad eyesight. The 
background of these differences certainly makes educational, cultural and other factors and should be separately analyzed.

Certain studies performed in the world also correlate with the results of our research in terms of positive attitudes towards inclusive education of children with special needs in teachers working with pupils of younger school age (Bender, Vail and Scott, 1995).

\section{CONCLUSION AND LIMITATIONS}

The aim of the research was to investigate the opinions and attitudes of teachers and professional associates in the Republic of Serbia towards inclusive education of children with special needs and compare the same with the views of teachers and associates in Norway.

The obtained results of performed research indicate that there is a generally positive attitude of teachers and professional associates in the Republic of Serbia towards inclusive education of children with special needs. These results provide a guarantee for future prospects and implementation of inclusive education in the Republic of Serbia.

The performed research did not show statistically significant differences in the attitudes of male and female participants in terms of inclusive education of children with special needs. However, the attitudes of teachers and professional associates in the Republic of Serbia towards inclusive education of children with special needs differ statistically and teachers generally have a more positive attitude towards all categories of students. The obtained results also imperatively impose conclusion for further needs on improving attitudes tow ards pupils with special needs in order to create certain support for additional implementation of inclusive education.

Mutual comparison of attitudes towards inclusive education of teachers and associates in the Republic of Serbia and Norway, showed interesting and significant differences according to certain categories of students with special needs. The existence of these differences points to the fact that some national, primarily educational, cultural and other factors play a significant role in the formation of positive attitudes towards inclusive education. These results highlight the need for greater and deeper comparative analysis of the concept of inclusive education. The limitation of the conducted research for wider generalizations is the size of the sample of teachers and professional associates, primarily from Norway.

The performed survey on the attitudes of teachers and professional associates towards inclusive education of students with special needs is a small contribution to the scientific study of inclusive education in the Republic of Serbia. Carefully conducted researches on the conditions and manner of implementation of inclusive education, as well as the development of strategies for support to the pupils with special needs in the regular system of education are the basis under which an argumentation for implementation 
of the idea of inclusive education must be sought. Actually these are "those questions" to which the answer must be given in order to make the idea of inclusive education possible and sustainable in practice.

Finally, we consider it necessary at this point to emphasize particularly the need to be aware of the fact that all children from the category of children with special needs (especially children with disabilities and handic apped children) cannot be involved in the educational process in educ ational institutions. Therefore, we believe that continuous and intensive management of researches and debates on inclusive education are necessary because of the need to form clear views on all aspects and possibilities of further changes in education from which all children will benefit. Also, we believe that any categorical rejection of inclusive education, or reckless acceptance, can lead to unpredic table consequences, both in the educ ational system, as well as in the development of each child with special needs. Only by such an approach the idea of quality education for all will be possible and achievable in practice.

\section{REFERENCES}

Angelides, P., Stylianou, T. \& Gibbs, P. (2006). Preparing teachers for inclusive education in Cyprus. Teaching and Teacher Education, 22(4), 94-99.

Avramidis, E., Bayliss, P. \& Burden, R. (2000). Student teachers attitudes towards the inclusion of children with special educational needs in the ordinary school. Teaching and Teacher Education, 16(3), 227-293.

Avramidis, E. \& Norwich, B. (2002). Teachers`attitudes toward integration/inclusion, A review of the literature. European Journal of Special Needs Education, 17(2), 129-147.

Bender, W. N., Vail, C. O. \& Scott K. (1995). Teachers`attitudes toward increased mainstreaming: Implementing effective instruction for students with learning disabilities. Journal of Learning Disabilities, 28, 87-94.

Buell, M. J., Hallam, R., Gamel-McCormick, M.\& Scheer, S. (1999). A Survey of General and special Education Teachers` Perceptions and Inservice Needs Concerning Inclusion. International Journal of Disability, Development and Education, 46(2), 143-156.

Carter, E. W. \& Hughes, C. (2006). Including high school students with severe disabilities in general education classes: perspectives of general and special educators, paraprofessionals and administrators. Research and Practice for Persons with Severe Disabilities, 31(2), 174-185.

Đorđević, S. (2010). Inkluzivno obrazovanje u osnovnoj školi - potreba ili pomodarstvo [Inclusive Education in primary schools - A Need or A Fad]. Наша школа [Our school], 1-2, 167-180.

Đorđević, S., Rapaić, D., Odović, G., Ilić, S. Arsić, R. \& Đorđević, L. (2016). Some theoretical consideration on inclusive education of attitudes and its implementation. In S. Potić, Š. Golubović \& M. Šćep anović (Eds.), INCLUSIVE THEORYAND PRACTICE-International Thematic Collection of Papers, (pp. 719). Novi Sad: Society of defectologists of Vojvodina. 
Hodkinson, A. (2007). Inclusive education and the cultural representation of disability and disabled people: recipe for disaster or catalyst of change? Research in Education, 77, 56-76.

Hrnjica, S. \& Sretenov, D. (2003). Deca sa razvojnim teškoćama u redovnim osnovnim školama u Srbiji-trenutno stanje i stavovski preduslovi za potencijalnu inkluziju [Children with Developmental Disabilities in Regular Schools in Serbia- Current Situation and Attitudinal Preconditions for Potential Inclusion]. Beograd: Ministarstvo prosvete i sporta i Save the Children.

Kasa Hendrickson, C. \& Kluth,P. (2005). We Have to Start With Inclusion and Work it Out as We Go: Purposeful Inclusion for Non-Verbal Students with Autism. International Journal of Whole Schooling, 2(1), 2-15.

Kunstmann, A. (2003). A path analy sis for factors affecting Head Start teacher` beliefs about inclusion. [Doctoral dissertation]. Columbus: Ohio State University.

Laws, G. \& Kelly, E. (2005). The attitudes and friendship intentions of children in United Kingdom mainstream schools towards peers with physical or intellectual disabilities. International Journal of Disability, Development and Education, 52(2), 79-99.

Leutar, Z. \& Štambuk, A. (2006). Stavovi mladih prema osobama s tjelesnim invaliditetom[Attitudes of Young People towards People with Physical Disability]. Revija za sociologiju, 37(1-2), 91-102.

Lifshitz, H., Glaubman, R. \& Issawi, R. (2004). Attitudes towards inclusion: the case of Israeli and Palestinian regular and special education teachers. European Journal of Special Needs Education,19(2), 172-190.

Martin, T. N. \& Vieceli, L. (1988). The business of rehabilitation placement: What to understand about private employers before approaching them. Journal of Rehabilitation, 54 (4), 49-55.

Najman Hižman, E., Leutar, Z. \& Kancijan, S. (2008). Stavovi građana prema osobama sa invaliditetom u Hrvatskoj u usporedbi s Evropskom unijom [Attitudes of Citizens towards People with Disabilities in Croatia in Comparison to the European Union]. Socijalna ekologija, 17(1), 71-93.

Pearce, M. (2009). The inclusive secondary school teacher in Australia. International Journal of Whole Schooling, 5(2), 1-13.

Rose, R. (2001). Primary school teacherperceptions of the conditions required to include pupils with special educational needs. Educational Review, 53(2), 147-157.

Ross-Hill, R. (2009). Teacher attitudes towards inclusion practices and special needs students. Journal of Research in Special Educational Needs, 9(3), 188-198.

Sharma, U., Forlin, C., Loreman, T. \& Earle, C. (2006). Pre-service teachersattitudes, concerns and sentiments about inclusive education: an international comparison of novice pre-service teachers. International Journal of Special Education, 21(2), 80-92.

Scruggs, T. E. \& Mastropieri, M. A. (1996). Teacher perceptions of mainstreming/ inclusion, Exceptional Children, 63(1), 59-74.

Soodak, L. C., Podell, D. M. \& Lehman, L. R. (1998). Teacher, student and school attributes

as predictors of teachers` responses to inclusion. The Journal of Special Education, 31(4), 480-497.

Tak-fai Lau, J. \& Cheung, C. (1999). Discriminatory attitudes to people with intellectual disability or mental health difficulty. International Social Work, 42(4), 431-444.

Tur-Kaspa, H., Weisel, A. \& Most, T. (2000). A multidimensional study of special education students attitudes towards people with disabilities: a focus on deafness. European Journal of Special Needs Education,15(1), 13-23. 


\title{
СТАВОВИ ПРЕМА ИНКЛУЗИВНОМ ОБРАЗОВАЬУ ИЗ ПЕРСПЕКТИВЕ УЧИТЕЉА И СТРУЧНИХ САРАДНИКА
}

\author{
Србољуб Ђорђевић ${ }^{1}$, Драгана Станојевић ${ }^{1}$, Луција Ђорђевић ${ }^{2}$ \\ ${ }^{1}$ Универзитет у Нишу, Педагошки факултет, Врање, Србија \\ ${ }^{2}$ ССС „Вуле Антић“ Врање, Србија
}

\begin{abstract}
Резиме
У раду се анализирају мишљења и ставови учитеља и стручних сарадника према инклузивном образовању и ученицима са посебним потребама у Републици Србији и Норвешкој и исти међусобно упоређују. Истраживање је спроведено у петнаест редовних основних школа које се налазе на територ ији Републике Србиje, на узорку од 220 учитеља и 22 стручна сарадника, као и 10 учитеља и 6 стручних сарадника двеју основних школа града Осла у Норвешкој. Техника истраживања је анкетирање, а инструмент истраживања је анкета осмишљена на основу постављеног циља и задатака истраживања. У истраживању је коришћена дескриптивна, аналитичка и компаративна метода. На основу добијених резултата истраживања, закључује се да постоји уопштено позитиван став учитеља и стручних сарадника у Републици Србији према инклузивном образовању деце са посебним потребама. Овакви резултати пружају гаранцију за даљу перспективу и увођење инклузивног образовања у Републику Србију. Извршеним истраживањем нису уочене статистички значајне разлике у ставовима мушких и женских испитаника по питању инклузивног образовања деце са посебним потребама. Међу тим, ставови учитеља и стручних сарадника у Републици Србији према инклузивном образовању деце са посебним потребама статистички се разликују и учитељи уопштено имају позитивнији став према свим категоријама ученика. Добијени резултати, такође, императивно намећу закључак да се и даље мора радити на побољшању ставова према ученицима са посебним потребама како би се стварала одрећена потпора за даље спровођење инклузивног образовања.

Међу собним упоређивањем ставова према инклузивном образовању учитеља и стручних сарадника у Републици Србији и Нор вешкој, уочили смо занимљиве и значајне разлике према појединим категоријама ученика са посебним потребама. Постојање ових разлика указује на чињеницу да неки национални, пре свега образовни, културни и други фактори, имају значајну улогу у формирању позитивних ставова према инклузивном образовању. Овакви резултати истичу потребу за већом и дубљом компаративном анализом концепата инклузивног образовања.
\end{abstract}

